\title{
POLLUTION STATUS OF SURFACE WATER RESOURCES IN ARID REGION OF RAJASTHAN (INDIA)
}

\author{
CHANCHAL KACHHAWA \\ Department of Chemistry \\ Government Engineering College, Bikaner (Raj.) INDIA \\ e_mail : chanchalkachhawa@gmail.com
}

\begin{abstract}
Present investigation deals with the evaluation of DO, BOD and COD of six surface water resources of Bikaner district which fall in arid region of Rajasthan - a part of Great Indian Desert, to determine pollution status. Water sample analysed for two years 2008-2009 showed these parameters beyond the limit of standard prescribed by WHO. These parameters also showed great seasonal fluctuation, indicating the degree of organic pollution more during summer season and least during winter season.
\end{abstract}

Keywords: DO, BOD, COD, Surface Water

\section{Introduction}

Water is vital to our basic existence. Drinking water quality determines well being of people. Without fresh water of an adequate quantity and quality, sustainable development will not be possible ${ }^{1}$. Deterioration of water quality is increasing day by day, and has now become a global problem ${ }^{2}$. Surface water quality is mainly controlled by geology of catchments area, agricultural uses and domestic discharge ${ }^{3}$.

Arid region of Rajasthan lies mainly in North-western zone of state, forms an important part of Great Indian Desert. Water is the most important limiting factor due to which frequent droughts are common in this region. The arid climatic conditions are extreme and great fluctuation in them during different seasons causes the variations in quality of source water. In such conditions, it is necessary to analyse the water sample, collected frequently over a long period of time to evaluate correlative change in water quality from drinking point of view. Thus, water quality is probably a more severe limitation than the scarcity of water itself in the region. Winter is quite cold and temperature sometimes reaches below $0{ }^{\circ} \mathrm{C}$ and summer is too scorching and temperature reaches upto $50{ }^{\circ} \mathrm{C}$. The rulers of this region were aware of water scarcity therefore, a number of lakes, ponds and dames were constructed during the recent past. These water bodies which once considered as divine source of water, are now increasingly being pathetically polluted. The pollution of surface water by discharge from human activities is one of the major environmental problems ${ }^{4-5}$. 
In present study, surface water resources of Bikaner district lying in the arid region of Rajasthan, were evaluated for Dissolved Oxygen (DO), Biochemical Oxygen Demand (BOD) and Chemical Oxygen Demand (COD) during different seasons to ascertain the occurrence of organic pollution. In this part, practically no surface run off and therefore, no river worth the name. Before the introduction of Indira Gandhi Canal, surface water resources were the main source of drinking water. The district can boast of only two small fresh water lakelets Kolayat and Gajner, founded by the drainage of the rocky country in the South-west of the district. An appreciable number of ponds (temporary or permanent) and open tank are in and around the city of Bikaner and in rocky country to face the scarcity of water.

\section{Materials and Methods}

The drinking water sample were collected in pre-washed polyethylene bottles fortnightly at random on a fixed date for two years 2008 and 2009 from 6 stations located in Bikaner district. Narrow mouth stopped bottle of $275 \mathrm{ml}$ capacity were used to determined the dissolved oxygen. These samples were subsequently stored at $4{ }^{\circ} \mathrm{C}$ for as short a time as possible before analysis to minimise physiochemical changes ${ }^{6}$. DO, BOD and COD were determined following the method of APHA $^{7}$.

\section{Results and Discussion}

Drinking water sources all over the world, are threatened not only by over exploitation and poor management but also by ecological degradation leads to water pollution. In arid region of Rajasthan the main reasons of the poor quality of water are the poor management, human interference, run off from agricultural field, geology of catchments area and also great fluctuation of environment conditions during different seasons of the year. Variations in the DO, BOD and COD determined during different season of year have been presented in the Table 1 .

Dissolved oxygen is very important in precipitating and dissolution of inorganic substances in water. Generally, natural water contain DO concentration ranging from about 4 to $14.5 \mathrm{mgL}^{-1}$ depending on the water temperature, salinity and altitude ( Parmer and Parmer, 2010). DO is the basis of BOD test, which is an important parameter to evaluate pollution potential of water bodies. DO was found to be ranged between $2.0 \mathrm{mgL}^{-1}$ to $10.5 \mathrm{mgL}^{-1}$ at station 5 (Summer-2009) and station 4 (Winter-2009), respectively. Average concentration of DO was found to be highest at station 4 (Kotri talab) in all the three seasons among all the station. In respect of season, its concentration was found to be maximum during winter season and minimum during summer season at all station. Similar trend has also been reported by Singh ${ }^{9}$.

BOD is a good index of organic pollution hence, it help in the determination of the suitability of water for use. Drinking water should have the BOD less than $1 \mathrm{mgL}^{-1}$ as recommended by $\mathrm{WHO}^{6}$. $\mathrm{BOD}$ values revealed marked seasonal variations being 
maximum during summer season and minimum during winter season at all station. It ranged from 1.5 to $8.6 \mathrm{mgL}^{-1}$.

COD values reveal the amount of dissolved oxidisable organic matter including the non-biodegradable matter in water body. The COD ranged from a minimum of 11.5 $\mathrm{mgL}^{-1}$ of station no. 4 (winter-2008) to maximum of $42.0 \mathrm{mgL}^{-1}$ of station no. 6 (Summer-2009), respectively. Average values of COD were observed to be more during summer season followed by rainy season and least during winter season at all station. The fluctuation in COD indicate the variation in degree of organic pollution during different seasons.

The minimum value of DO and maximum value of BOD during the summer season can be explained on the ground that rise in water temperature reduced the solubility of oxygen in water, enhances the microbial activity and metabolic rate. Low DO during summer may also be due to high turbidity of water ${ }^{10}$.

\section{Conclusion}

A series of oxygen determinations can reveal more about the water body than other parameters. The occurrence of DO in water is mainly due to physical and biological processes. The concentration of DO varied from season to season. All the surface water resources studied except Kotri talab showed the limit of DO much below the minimum permissible limit, and BOD and COD much above the maximum permissible limit.

\section{References}

1. N. Kumar, A view of freshwater environment Ecol. Env. and Cons. 3 (3-4) 312-317 (1997).

2. H.B. Mahananda, M.R. Mahananda, and B.P. Mohanty. Studies on the physico-chemical and biological parameters of a fresh water pond ecosystem as an indicator of water pollution. Ecol. Env. and Cons. 11 (3-4) : 537-541 (2005).

3. A. Tiri, and A. Boudoukha, Hydrochemical analysis and assessment of surface water quality in Kondiat Medouar Reservoir, Algeria. Eu. J. Sci. Res. 41(2) : 273-285 (2010).

4. S. Singh, and L.M. Mosley, Trace metal levels in drinking water on Viti Lever, Fiji Island. $S$. Pac. J. Nat. Sci. $21: 31-34$ (2003).

5. N. Peter, O. Bricker, M. Kennedy, Water Quality Trends and Geochemical Mass Balance. John Wiley \& Sons, New York, NY, USA. pp 103-137 (1997).

6. WHO. Guidelines for Drinking Water Quality, Geneva. 2 : 231 (1996).

7. APHA-AWWA-WPCF. Standard Methods for Examination of Water and Waste Water. American Public Health Association, Washington D.C. (17 ${ }^{\text {th }}$ ed.) pp. 1452 (1989).

8. K. Parmar, and V. Parmar. Evaluation of water quality index for drinking purposes of river Subernarekha in Singhbhum District. Int. J. Env. Sci. 1 : 77-81 (2010).

9. B.B. Singh. Pollution status of Rapti River at Gorakhpur, J.Env. Pol. 2(3) : 117-120 (1995).

10. Quasim, S.Z. Wellerlshaus, S.Bhattathriri, P.M.A. and Q. Abidi S.A.N. Organic production in a tropical estuary. Proc. Ind. Acad. Sci. 2 : 51-94 (1969). 